\title{
INDOL-BUTYRIC ACID LEVELS ON CASHEW CLONING BY AIR-LAYERING PROCESS ${ }^{1}$
}

\author{
RODRIGO LUIZ LOPES², ÍTALO HERBERT LUCENA CAVALCANTE³, INEZ VILAR DE MORAIS OLIVEIRA4, \\ ANTONIO BALDO GERALDO MARTINS ${ }^{5}$
}

\begin{abstract}
A study was conducted to determine the possibility of cashew (Anacardium occidentale) cloning by air-layering and influence of IBA (indol-butyric acid) on this process. It was adopted a completely randomized design with 4 treatments, 10 air layers each and 4 replications, reaching 160 air layers. The IBA levels on the treatments were, as follow: 0, 1000, 3000 and $5000 \mathrm{mg} \cdot \mathrm{kg}^{-1}$. It was evaluated: survival, callus and rooting percentage, average number and length of roots. The highest survival rate $(67.5 \%)$ was registered with no growth regulator and IBA at $1000 \mathrm{mg} . \mathrm{kg}-$ ${ }^{1}$, while the best rooting percentage $(82 \%)$ referred to $1000 \mathrm{mg} \cdot \mathrm{kg}^{-1}$. In spite of average number and length of roots, the highest results were observed with IBA at $5000 \mathrm{mg} \cdot \mathrm{kg}^{-1}$. IBA concentrations had no influence on cashew air-layering formation.
\end{abstract}

Index terms: Anacardium occidentale, plant growth regulator, vegetative propagation.

\section{NÍVEIS DE ÁCIDO INDOLBUTÍRICO NA CLONAGEM DO CAJUEIRO PELO PROCESSO DE MERGULHIA AÉREA}

RESUMO- Um estudo foi conduzido com a finalidade de determinar a possibilidade de clonagem do cajueiro (Anacardium occidentale) por alporquia e a influência do AIB (ácido indolbutírico) nesse processo. Adotou-se delineamento experimental inteiramente casualizado, com 4 tratamentos, 10 alporques por parcela, repetidos por 4 vezes, num total de 160 alporques. Os tratamentos constaram das concentrações de AIB: 0 (testemunha), $1.000,3.000$ e $5.000 \mathrm{mg} \cdot \mathrm{kg}^{-1}$. Foram avaliadas as percentagens de sobrevivência, calejamento e enraizamento, bem como número e comprimento médio de raízes. A maior percentagem de sobrevivência (67,5\%) foi observada para a testemunha e concentração de $1.000 \mathrm{mg}$. $\mathrm{kg}^{-1}$, enquanto a melhor percentagem de enraizamento (82\%) foi relacionada com o nível de $1.000 \mathrm{mg} . \mathrm{kg}^{-1}$. Para o número e comprimento médio de raízes, os melhores resultados foram concernentes à dose de $5.000 \mathrm{mg} \cdot \mathrm{kg}^{-1}$. Não houve influência do AIB na clonagem do cajueiro por alporquia.

Termos para indexação: Anacardium occidentale, regulador de crescimento, propagação vegetativa.

Cashew species Anacardium occidentale is cultivated in tropical regions of the world. Cashew production is centralized in ThirdWorld countries like India (460.000t), Nigeria (186.000t), Brazil (178.343t) and Tanzania (123000t) (FAO, 2004), although Tanzania orchards presented the highest level of technology.

In Brazil, the Northeast Region differs with large cultivated areas mainly in Ceará, Piaui, Rio Grande do Norte and Maranhão States (Agrianual, 2004), however low yield rates due to factors as genetic variability in plants (Barros et al., 2000), lack of irrigation and conduction of orchards with no adequate management of soil, pests and diseases. In São Paulo State this fruitful area is widely distributed, there are commercial orchards and possibility of expansion.

Cashew tree can be propagated by sexual or asexual way, this last one involving grafting, cutting and layering. The preferred method in Brazil is grafting which has presented potential results for commercial applying; however it is necessary a long time to obtain few seedlings.

Rooting process in cashew propagation is very difficult (Ferrão, 1995). Due to this reason alternative rooting forms have been studied by the use of cutting exudation solution (Mnemey \& Mantell, 2003) or indicated plant growth regulators as IBA (indol-butyric acid) and NAA (naphthalene acetic acid), nevertheless it's necessary to determine the best concentration of these products specifically for cashew. Another option is the study of new alternatives, perhaps by culture tissue (Martin, 2003, Ananthakrishnan et al., 2002).

Air-layering constitutes the vegetative propagation process with higher success in cashew (Azam-Ali \& Judge, 2001). It's a fast plant multiplication process which totally reproduces the genetic plant characteristics but presents a high death rate in field, mainly after seedling transplantation. Other researches demonstrate the air-layering viability (Almeida et al., 1992).

The work had as objective to identify the influence of indolbutyric acid on cashew air layering process.
The experiment was realized in Faculdade de Ciências Agrárias e Veterinárias, Universidade Estadual Paulista, Jaboticabal-SP. The climate is classified as Cwa with rainy average $1400 \mathrm{~mm}$ per year and temperatures between 18.5 and $25^{\circ} \mathrm{C}$.

Air layers were prepared in twenty year plants $\mathrm{CP}-76 \mathrm{cv}$, on invigorated shoots, located on the medium portion of canopy. A strip of bark about $0.5 \mathrm{~cm}$ wide was removed from either branch at about $50 \mathrm{~cm}$ length and $1.0 \mathrm{~cm}$ diameter from the growing point. At this incision it was applied treatments constituted by different IBA (indol-butyric acid) concentrations, as follows: 0, 1000, 3000 and $5000 \mathrm{mg} \cdot \mathrm{kg}^{-1}$. These concentrations were prepared by auxin dilution in lanolin paste.

A completely randomized design was adopted and 4 treatments were performed in 4 replications of 10 air layers, reaching 160 air layers.

It was registered, 90 days after IBA supply, data referring to: survival, callus formation and rooting percentage (for survived air layers), average number and length of roots.

The results were submitted to variance analysis by $\mathrm{F}$ test and Tukey test for comparison of averages at each variable.

IBA concentration had no statistical influence on survival percentage of cashew air layers. It was observed the lowest rate $(42.5 \%)$ with IBA at $5000 \mathrm{mg} \cdot \mathrm{kg}^{-1}$ and the highest one (67.5\%) with no growth regulator and IBA at $1000 \mathrm{mg} \cdot \mathrm{kg}^{-1}$. These results are above those registered by Shetty and Melanta (1990) with a maximum survival rate of $97.5 \%$ for cashew air layers with a $3000 \mathrm{mg} \cdot \mathrm{kg}^{-1} \mathrm{IBA}$ concentration.

In relation to callus percentage, the results ranged between 18.00 and $20.75 \%$, referring to 1000 and 5000 mg. $\mathrm{kg}^{-1}$ IBA levels respectively, therefore with no influence of IBA concentrations on callus formation percentage (Figure 1). In research about Diospyros kaki, Biasi et al. (2002) adopted IBA levels from 0 to $4000 \mathrm{mg} \cdot \mathrm{kg}^{-1}$ and related that there was callus formation just in treatments where a strip of bark was removed, independent of IBA concentration, nevertheless in agreement with these data research.

\footnotetext{
${ }^{1}$ (Trabalho 148/2004). Recebido: 28/10/2004. Aceito para publicação: 17/11/2005.

${ }^{2}$ Estudante de Agronomia FCAV/UNESP, Jaboticabal-SP.

${ }^{3}$ Pós-graduando em Agronomia, Departamento Produção Vegetal (Horticultura), Universidade Estadual Paulista, Faculdade de Ciências Agrárias e Veterinárias (UNESP/FCAV), Câmpus de Jaboticabal. Via de acesso Prof. Paulo Donato Castellane s/n, CEP 14.884-900, Jaboticabal-SP. Tel.: 16 3209 2668. e-mail: italohlc@fcav.unesp.br.

${ }^{4}$ Pós-graduando em Agronomia, Departamento Produção Vegetal, UNESP/FCAV. e-mail: inezvilar@yahoo.com.

${ }^{5}$ Prof. Dr., Departamento Produção Vegetal, UNESP/FCAV. e-mail: baldo@fcav.unesp.br.
} 
As can be seen in Figure 1 the use of IBA at $0-500 \mathrm{mg} \cdot \mathrm{kg}^{-1}$ had no influence on root percentage of cashew air layers. It was registered a $79.38 \%$ average, with values that varied from $79.25 \%$ with no growth regulator and $82 \%$ with IBA at 1000 mg.kg-1. In study about Barbados cherry, that is a hard rooting species, Gontijo et al. (2003) observed that $50 \%$ of cuttings from $2800 \mathrm{mg} \mathrm{L}^{-1} \mathrm{IBA}$ concentration rooted. Hartman et al. (1997) reported that rooting process can be determined, beyond other factors, by the clone in study. Although $79.38 \%$ of rooting, it was registered survive average rate of $60 \%$ and there were few and short roots formed, that probably will not provide the seedling.

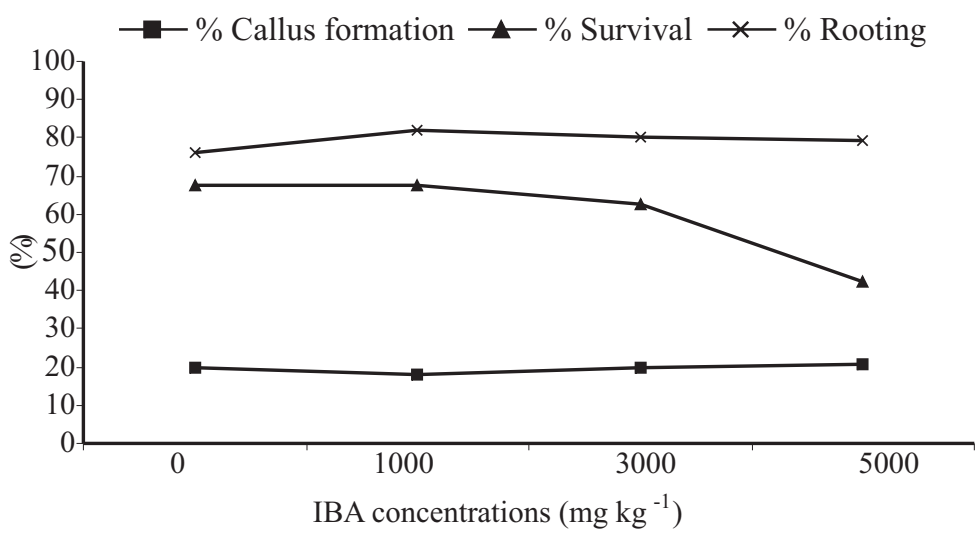

FIGURE 1 - Effect of IBA concentration on survival, callus formation and rooting percentage of cashew air-layers.

The average number of roots in air layer was not influenced by the growth regulator used (Figure 2). The range from 4 to 6 is in agreement with 5 indicated by Azam-Ali \& Judge (2001) for air-layering process and 5 registered by Melanta \& Sulladmath (1990) for cutting, both with no growth regulator use.

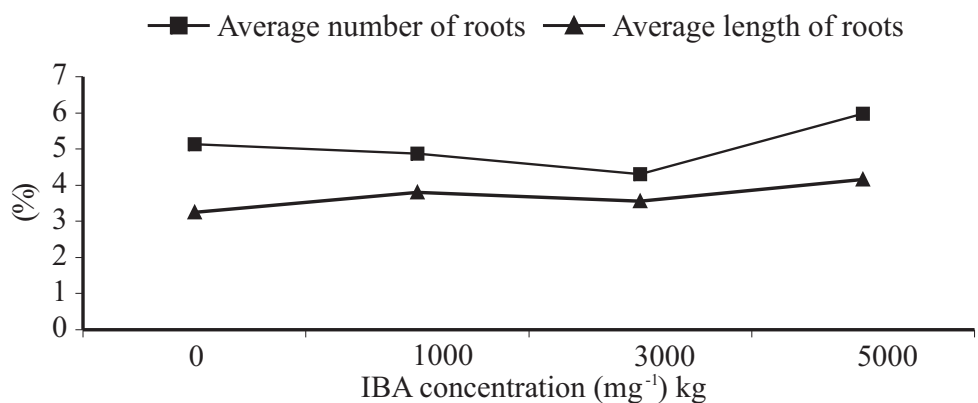

FIGURE 2 - Effect of IBA concentration on average number and length of cashew air layer roots.

In relation to average length or roots (Figure 2) the results are above to values mentioned at the literature, however with no statistic difference among IBA concentrations. The $3.7 \mathrm{~cm}$ average is above to 1.0-1.5 cm range indicated by Azam-Ali \& Judge (2001) for cashew airlayers, possibly due to the clone studied. Comparably to cutting process, these values are below to maximum $(17.7 \mathrm{~cm})$ referred by Melanta \& Sulladmath (1990) for cashew cuttings with IBA at $2000 \mathrm{mg} \cdot \mathrm{kg}^{-1}$.

IBA concentrations do not influence survival, callus formation and rooting percentage; average number and length of roots on cashew air-layering process.

\section{REFERENCES}

AGRIANUAL 2004: anuário estatístico da agricultura brasileira. São Paulo: FNP Consultoria e comércio, 2004.

ALMEIDA, F.A.G;;ALMEIDA, F.C.G;ALBUQUERQUE, J.J.L.; RABELO FILHO, M.A. Poda da raiz na produção de mudas de Anacardium occidentale L. através da alporquia. Revista de La Faculdad de Agronomia, Maracay, v. 18, p. 39-46, 1992.

ANANTHAKRISHNAN, G.; RAVIKUMAR, R.; GIRIJA, S.; GANAPATHI, A. In vitro adventitious shoot formation from cotyledon explants of cashew (Anacardium occidentale L.). Scientia Horticulturae, Wageningen, v. 93, n. 3-4, p. 343-355, 2002.

AZAM-ALI, S. H.; JUDGE, E. C. Small-scale cashew nut processing. Rugby,UK: FAO, 2001.

BARROS, L.M.; CAVALCANTI, J.J.V.; PAIVA, J.R. de; CRISÓSTOMO, J.R.; CORRÊA, M.P.F.; LIMA, A.C. Seleção de clones de cajueiroanão para o plantio comercial no Estado do Ceará. Pesquisa Agropecuária Brasileira, Brasília, v.35, n. 11, p. 2197-2204, 2000.

BIASI, L. A.; CARVALHO, D. C.; WOLF, G. D.; ZANETTE, F. Potencial organogenético de tecidos caulinares e radiculares de caquizeiro. Revista Brasileira de Fruticultura, Jaboticabal, v.24, n.1, p.29-34. 2002.

FAO. FAOSTAT - Statistics database. Disponível em: $<$ http:// apps.fao.org>. Acesso em: 01 nov. 2004.

FERRÃO, J. E. M. O cajueiro. Lisboa: Instituto de Investigação Científica Tropical, 1995. 299 p.

GONTIJO, T. C. A.; RAMOS, J. D.; MENDONÇA, V.; PIO, R.; ARAÚJO NETO, S. E.; CORREAA, F. L. O. Enraizamento de diferentes tipos de estacas de aceroleira utilizando ácido indolbutírico. Revista Brasileira de Fruticultura, Jaboticabal, v.25, n.2, p.290-292, 2003.

MARTIN, K. P. Plant regeneration through direct somatic embryogenesis on seed coat explants of cashew (Anacardium occidentale L.). Scientia Horticulturae, Wageningen, v. 98, n. 3, p. 299-304, 2003.

MELANTA, K. R.; SULLADMATH, U. V. Studies on propagation of cashew (Anacardium occidentale L.) by cuttings. Mysore Journal of Agricultural Sciences, Mysore, v. 24, n. 1, p. 79-82, 1990.

MNENEY, E. E.; MANTELL, S. E. Effect of deliberate wounding and natural cashew gum extracts in improving rooting and resilience of cashew cutings post-excision. Research \& Training Newsletter, Dar es Salaam, v. 18, n. 1-4, p. 8-11, 2003.

SHETTY, K. K.; MELANTA, K.R. Hardening of cashew (Anacardium occidentale L.) air layers in planting media to improve field establishment. Mysore Journal of Agricultural Sciences, Mysore, v.24, n. 3, p. 375-378, 1990. 